\title{
Isolation, Production and Characterisation of Novel Gelatinase Enzyme From Bacillus Spp
}

\author{
Jini Joseph $^{1 *}$, Harsha Sasidharan ${ }^{2}$, Chithira O.S \\ ${ }^{1,2,3}$ Department of Biotechnology, St.Peter's College, Kolenchery, Kerala- 682311, India \\ "Corresponding Author: jinijsph@gmail.com
}

Available online at: www.isroset.org

Received: 21/Nov/2018, Accepted: 19/Dec/2018, Online: 31/Dec/2018

\begin{abstract}
Nowadays gelatinase have received considerable attention as targets for drug development because of their potential role in connective tissue degradation associated with tumor metastasis. The potential uses of Gelatinase and their high demand, necessitates the need for the discovery of new strains of bacteria that produce enzymes with novel properties and with low cost industrial medium. The present study was conducted to isolate and identify gelatinase producing microorganisms as well as optimize the medium and cultural conditions for maximum enzyme production. Isolates obtained from fish processing wastes were examined for gelatinase production.The medium parameters were optimized for maximum production of gelatinase enzyme by the efficient isolate.Optimizing its abiotic factors, maximum enzyme activity was achieved at $48 \mathrm{~h}$ incubation period, $\mathrm{pH} 7,40^{\circ} \mathrm{C}$ temperature, lactose as carbon source and a gelatin concentration of $0.2 \%$. The identity of the strain was confirmed by PCR reaction with universal primers ( $27 \mathrm{~F}$ and $1492 \mathrm{R})$, sequencing and then by the BLAST analysis. The results showed that the isolated bacteria had highest homology (100\%) with Bacillus thuringiensis strain O3.The enzyme produced under all the optimum was then purified by ammonium sulphate precipitation (40\%) and dialysis. The final purification after dialysis yielded specific activity of $45.85 \mathrm{IU} / \mathrm{ml}$. The purity of enzyme preparation was assessed by SDS PAGE Gel electrophoresis and was found to be a single band with a molecular weight of approximately $66 \mathrm{kDa}$. The study could isolate and identify a potent gelatinase producing Bacillus strain that can be used for the development of gelatinase enzyme production.
\end{abstract}

Keywords: Gelatinase, Gelatin agar, BLAST, Dialysis, PCR, SDS PAGE, Bacilli

\section{I.INTRODUCTION}

Enzymes are produced by every living organisms, however, microbial enzymes have several advantage over the enzymes derived from plants or animals sources by virtue of their great variety of catalytic activities, cheaper in cost and relatively more stable[1].Fish by-products provide an excellent source for microbial growth, which can be exploited in producing various metabolites (lysine, enzymes, etc.) $[2,3]$. A large number of microorganisms including bacteria, yeast and fungi produce different groups of enzymes (protease, lipase, etc.) having high biotechnological interest (food processing, detergent, textile, pharmaceutical products, medical therapy, etc.)[4]. Microbial synthesis of enzymes has been reported to be influenced by various factors such as carbon sources, nitrogen sources, and operating parameters (temperature, $\mathrm{pH}$, etc.) $[5,6,7,8]$. Generally, agro-industrial residues mainly composed of complex polysaccharides are considered the best substrates for microbial growth and enzyme production[9]. The economies of this process are governed mostly by the cost and availability of a suitable carbon and nitrogen sources. Therefore, the investigation of low cost substrates easily available such as fish processing wastes became a necessity opening new avenues for their effective production and utilization.

Gelatinases are proteases and found in humans as matrix metalloproteinases (MMP 2 and 9) which break down extracellular matrix, playing a role in embryonic development, morphogenesis, reproduction and tissue remodelling as well as in diseases like arthritis, cardiovascular and neurological diseases and also cancer and metastasis hence, they are medically important as targets for drug development [10,11,12,13]. It has been proved that bacterial metalloproteases are associated with virulence and matrix metalloproteases of eukaryotes play a significant role in processing of precursors which play modulation roles in tumourformation [14,15]. Metalloproteases have thus attracted considerable attention for development of inhibitors for disease treatment [16]. Gelatinases have role in connective tissue degradation associated with tumour metastasis; hence, they are medically important as targets for drug development $[10,11]$. 
Gelatinases A and Gelatinase B cleave gelatins and also types IV and V collagens [17] and elastin [18].In this study, an attempt has made to probe for potential gelatinase bacterial producer which makes a promising strain with desired nature for industrial large scale production.

Section I contains the introduction of gelatinase enzyme and its importance, Section II contain the related work of gelatinase enzyme, section III explains the methodology by which the study was conducted, Section IV describes results came out after the study and the work supported the study, Section V contain discussion and Section VI concludes research work with future directions.

\section{RECENT WORK}

Boucas et al.(2008)[19] studied the effects of environmental and nutritional factors on gelatinolytic activity by Enterococcus faecalis strains isolated from clinical sources. Mazotto et al.(2010) [20] isolated Bacillus subtilis AMR from poultry waste with keratinaseandgelatinase activity that hydrolysed human hair indicating that the peptides obtained mayfind applications in pharmaceutical and cosmetic formulations.

Mazollo et al.(2011) [21]reported the isolation of Bacillus sp. from agroindustrial residues in a poultry farm, which could degrade gelatine, keratin, casein etc. They demonstrated that featherwaste could be used as a cheap and ecofriendly substrate for the enzyme.

Shanmughasundaram Senthil Balan et al. (2012) [22] studied on the production of gelatinase enzyme from Bacillus spp isolated from the sediment sample of Porto Novo Coastal sites.

Maurice Ekpenyong et al. (2016)[23] worked on the production and activity kinetics of gelatinase by Serratia sp.SLO3.

\section{MATERIALS AND METHODS}

Collection and Isolation of Gelatinase producing bacteria Sediment samples were collected from eight different fish market in and around ErnakulamDist, Kerala. The central portion of the collected samples were aseptically transferred to sterile polythene bags and carried to the laboratory and maintained at $4^{0} \mathrm{C}$ for further study. The collected sediment samples were serially diluted and spread plated on gelatin agar and incubated for $48 \mathrm{hrs}$ at $37^{\circ} \mathrm{C}$.

\section{Detection of gelatinolytic bacteria (Primary screening)}

After incubation period, bacterial colonies were observed on gelatin agar plate. The plateswere examined for gelatinase producing strain using $15 \%$ mercuric chloride in $20 \%(\mathrm{v} / \mathrm{v})$ concentrated $\mathrm{HCl}$ solution which is used as protein precipitating agent. From the gelatin agar plate the gelatinolytic bacterial colonies were collected for further study.

\section{Gelatin liquefaction test}

For the conformation of gelatinase enzyme production, gelatin liquefaction test was done by stabbing gelatin agar deep tubes[24,25]. The isolates that liquefied gelatin was considered positive for gelatinase enzyme production and used for further quantitative study.

\section{Enzyme assay}

Gelatinase enzyme assay was done according to the method of Tran and Nagano (2002)[26]. The reaction mixture contained $0.3 \mathrm{ml}$ of $(0.2 \%)$ gelatin in water, $0.2 \mathrm{ml}$ of $(150$ $\mathrm{mM})$ Tris- $\mathrm{HCl}, \mathrm{pH} 7.5,12 \mathrm{mMCaCl}_{2}$, and $0.1 \mathrm{ml}$ sample (crude enzyme). The mixture was incubated at $30^{\circ} \mathrm{C}$ for 30 min and stopped by addition the addition of $0.6 \mathrm{ml}$ of $(0.1 \mathrm{~N})$ $\mathrm{HCl}$. The released free amino group's amount was measured by the Ninhydrin method [27].Gelatinase activity is expressed as $\mu \mathrm{mol}$ of leucine equivalent per $\mathrm{min} / \mathrm{ml}$ of the culture filtrate [28]. The same mixture except gelatin was used as blank.

\section{Optimization studies for maximum gelatinase production}

The selection of the best medium components and their concentrations plays an important role in product development. Further, environmental parameters like $\mathrm{pH}$, temperature also have a major its role in it. The experiments were conducted in $250 \mathrm{ml}$ Erlenmeyer flask containing gelatinase production medium [22] and the average values were calculated. The range of parameter achieved by one step was fixed in subsequent experiments.

\section{Incubation period}

In order to check the effect of Incubation period on gelatinase enzyme production, the fermentation medium was incubated for $12 \mathrm{~h}, 18 \mathrm{~h}, 24 \mathrm{~h}, 48 \mathrm{~h}$ and $60 \mathrm{~h}$ and the gelatinase enzyme production was estimated.

pH

The $\mathrm{pH}$ of the medium was optimized between the ranges 6 to 10 with intervals of 1 in the basal medium for maximum gelatinase production.

\section{Temperature}

To evaluate gelatinase activity at different temperature, the crude enzyme wasincubated at $20^{\circ} \mathrm{C}$ to $60^{\circ} \mathrm{C}$ with an interval of $10^{\circ} \mathrm{C}$.

\section{Carbon sources}

The influence of different carbon sources like glucose, fructose, lactose, maltose, starch, was tested for obtaining maximum gelatinase production.

\section{Substrate concentration}


In order to check the Influence of enzyme substrate gelatin for maximum enzyme production, substrate concentration ranging from $0.2 \%$ to $1 \%$ with an interval of $0.2 \%$ was used.

\section{Molecular Identification of Bacteria}

Polymerase chain reaction allows amplification of specific DNA sequences. Pure culture of the target Bacteria was grown overnight on nutrient broth for the isolation of DNA. The DNA was isolated from the bacteria using phenolchloroform method [29] and 16S rDNA was amplified by Thermocycler (Eppendorff) using the universal primers, 27F and 1492R[30]. The PCR was performed in $50 \mu 1$ reaction mixture containing $5 \mu \mathrm{l}$ of $10 \mathrm{X}$ assay buffer, $4 \mu \mathrm{l} \mathrm{dNTP}$ mix, $1 \mu \mathrm{l}$ each of forward and reverse primer $(100 \mu \mathrm{mol}), 0.3 \mu \mathrm{l}$ of Taq polymerase, $5 \mu 1$ of template DNA and $33.7 \mu$ of HPLC grade water.

The amplified 16S rDNA PCR product was sequenced using automated sequencer (SciGenom Labs Pvt Ltd, Kochi, India.). The Sequence Similarity search was done for the 16S rDNA sequence using online search tool called BLAST. The unknown organism was identified using the maximum aligned 16SrRNA sequences available in the GenBank of NCBI through the BLAST search. The best sequence alignment results were noted.

\section{Phylogenetic Tree}

The 16S rRNA sequence of microbial isolate MSI was analysed using BLASTn tool in NCBI. Multiple Sequence Alignment was performed using MEGA 6 software. On the basis of these results a phylogenetic tree was constructed which indicated the evolutionary relationship of microbial isolate MSI with closely related species.

\section{PURIFICATION OF GELATINASE ENZYME} Partial purification by ammonium sulfate precipitation and dialysis.

Partial purification of the enzyme was done by ammoniumsulphate precipitation method. The gelatinase enzyme in the extracts from the bacterial strains was purified by salting out with ammonium sulphate. The resultant precipitate was dissolved in $5 \mathrm{ml}$ of distilled water and dialyzed overnight against phosphate buffer of $\mathrm{pH} 7$ in a cellophane bag with a molecular weight cut off $10 \mathrm{KDa}$.

\section{SDS-PAGE}

SDS-PAGE was carried out with the SDS tris glycine system. Crude enzyme was dissolved in Tris- $\mathrm{HCl}$ buffer $(\mathrm{pH}$ 6.8) containing 0.5 per cent each of SDS and mercaptoethanol and was kept in a boiling water bath for 3 min in a tightly stoppered vial. For molecular weight determination, the standard protein used was Bovine Serum Albumin (BSA) (66kD)

\section{RESULTS}

Isolation and preliminary screening of gelatinase producing bacteria Eight different samples were collected from different fish markets in and around Ernakulum districtin Kerala. The gelatinase producing bacteria were initially analyzed for their ability to degrade gelatin, for that the nine samples were pour plated on gelatin agar media and kept on incubation period of 48 hours,from that the isolate which show maximum gelatin degradation was selected (Fig.1)

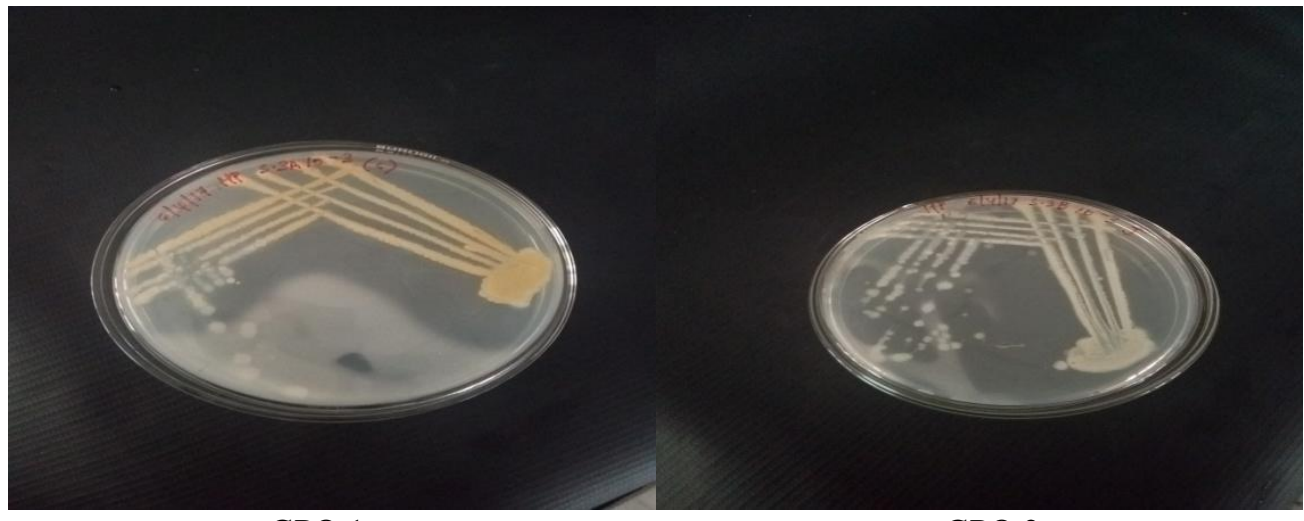

GPO 1

GPO 2

Fig 1.Bacillusspp showing gelatinase activity against $\mathrm{HgCl}_{2}$ solution in gelatin agar

After the incubation period,theplateswere flooded with mercuric chloride solution. The bacterial colonies that produced gelatinase enzyme showed a clear zone around the colonies indicates that the isolate have the ability to produce gelatinase enzyme. Sample which marked as GPO 1 and GPO 2 showed maximum zone and these strains were subjected to gelatin liquefaction assay. If gelatin was hydrolyzed, the medium will remain liquid after refrigeration. Both culture remain as liquid after refrigeration which shows conformation of gelatinase enzyme from the colonies (Fig. 2). 


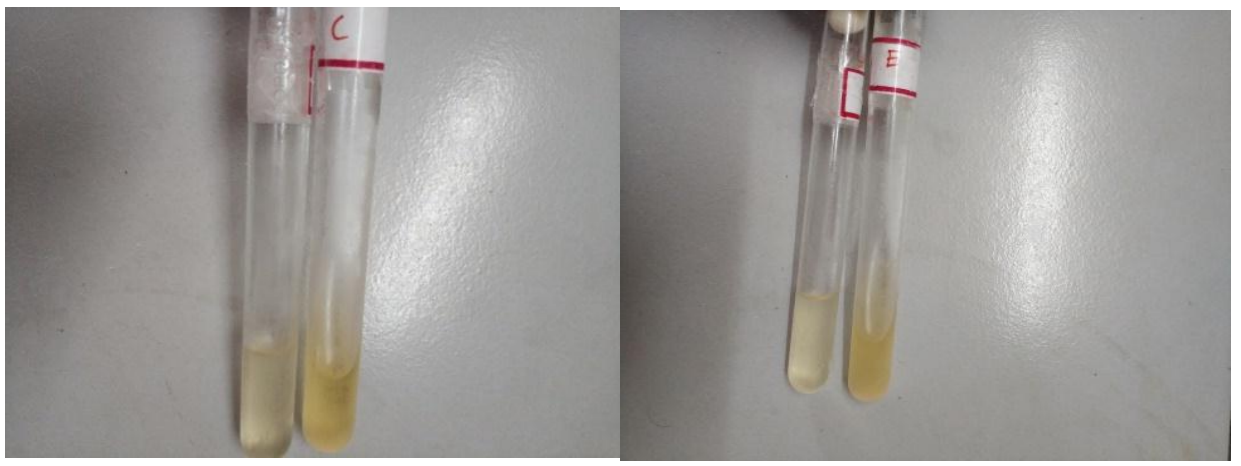

Fig.2: Gelatin liquefaction test

The potential bacterium was selected based on the results obtained from zone measurement of axenic cultures on the gelatin agar (fig.1) Out of which, strain GPO 1 produced maximum zone formation was selected for further studies.

\section{Morphological, cultural and biochemical characteristics}

A microscopic examination revealed that the isolates were Gram positive spore forming bacteria. Furthermore, the biochemical analysis of the isolates was performed and identified to be Bacilli species. Their colonial, morphological, and biochemical characteristics are tabulated in Table

Table 1: Morphological Identification of Bacteria

\begin{tabular}{|l|l|}
\hline Morphology & GPO 1 \\
\hline Shape & Round \\
\hline Margin & Entire \\
\hline Elevation & Raised \\
\hline Size & Moderate \\
\hline Texture & Smooth \\
\hline Pigmentation & Absent \\
\hline Opacity & Opaque \\
\hline Gram staining & Gram positive \\
\hline
\end{tabular}

Table 2: Biochemical Identification

\begin{tabular}{|c|c|c|c|c|c|c|c|c|c|}
\hline Sample & $\begin{array}{c}\text { Indole } \\
\text { test }\end{array}$ & $\begin{array}{c}\text { MR } \\
\text { test }\end{array}$ & $\begin{array}{c}\text { VP } \\
\text { test }\end{array}$ & $\begin{array}{c}\text { Citrate } \\
\text { test }\end{array}$ & $\begin{array}{c}\text { Urease } \\
\text { test }\end{array}$ & $\begin{array}{c}\text { Sugar } \\
\text { fermentation } \\
\text { test }\end{array}$ & $\begin{array}{c}\text { Starch } \\
\text { hrdrolysis } \\
\text { test }\end{array}$ & $\begin{array}{c}\text { Protease } \\
\text { test }\end{array}$ & $\begin{array}{c}\text { Catalase } \\
\text { test }\end{array}$ \\
GPO 1 & -ve & +ve & -ve & -ve & -ve & -ve & -ve & + +ve & + +ve \\
\hline
\end{tabular}

\section{Molecular identification of gelatinolytic bacteria}

Being highly sensitive and selective, molecular methods are currently used to identify microorganisms. The strains were further subjected to molecular identification by analyzing $16 \mathrm{~S} r$ RNA sequence. By using these primers a partial sequence of $16 \mathrm{~S}$ rRNA gene was amplified. Genomic DNA 
was used as template for PCR amplification of $16 \mathrm{~S}$ rRNA(fig.3). An amplicon size of approx.1500 base pairs (bps) was observed in agarose gel electrophoresis (Fig. 4).The size of amplified PCR product was determined by $2.5 \%$ agarose gel electrophoresis using DNA markers of $500 \mathrm{bp}$. The amplified 16S rRNA PCR product was sequenced at SciGenom Labs PvtLtd, Cochin, Kerala using forward (fig.5) and reverse primers (fig.6). The isolate was then identified using the maximum aligned sequence through BLAST search (Fig.7). BLAST results indicated $100 \%$ identity of GPO 1 sample with Bacillus thuringiensisstrain O3, Bacillus cereus R2.8, Bacillus cereus R2.4 gene, Bacillus cereus R2.2, Bacillus cereus R1.10 gene (Fig 8). Gene sequence of $16 \mathrm{~S}$ rRNA was compared with sequences available in databases. The nucleotide sequences of the amplicon was submitted to NCBI and Phylogenetic tree was generated which shows the evolutionary relatives of the organism . Bacillus thuringiensis strain $\mathrm{O} 3$ showed a highest homology with Bacillus taiwanesis strain and Bacillus gaemokensisstrain(Fig 9).

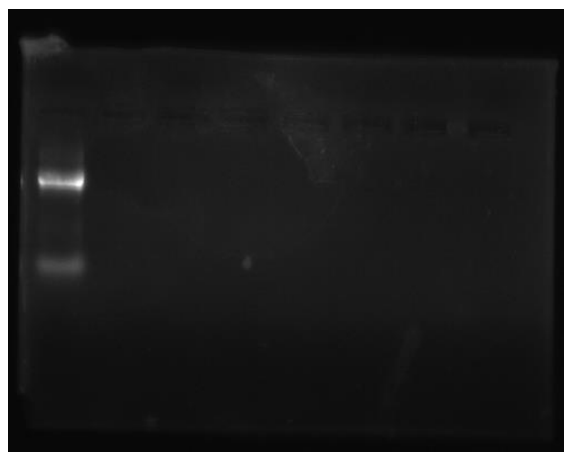

Figure 3: DNA isolation

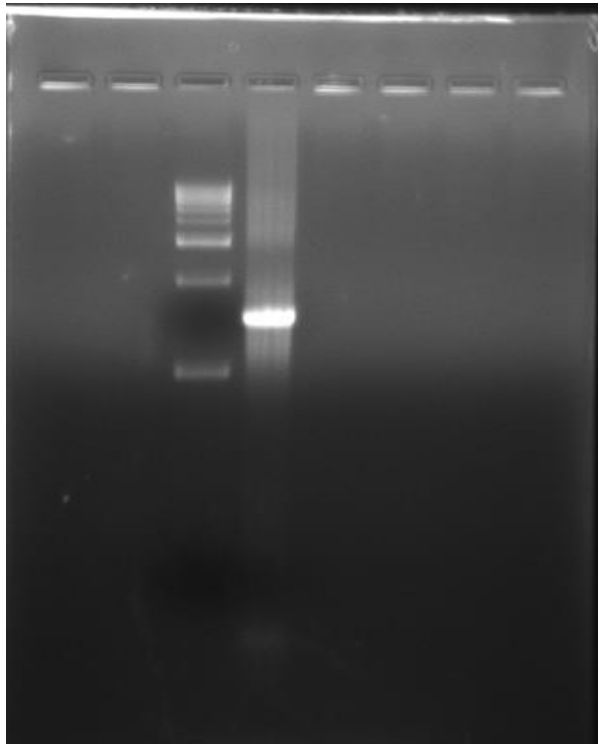

Figure 4 Polymerase Chain Reaction

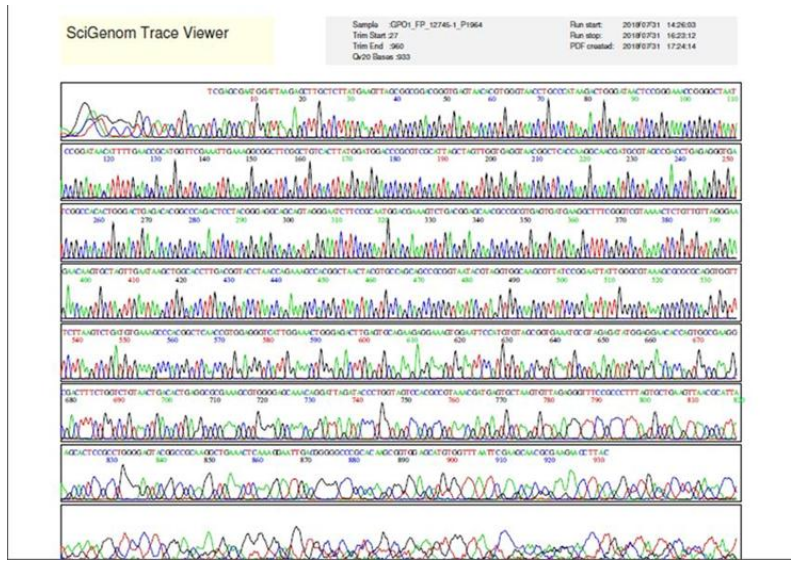

Fig. 5Sequencing (forward primer)

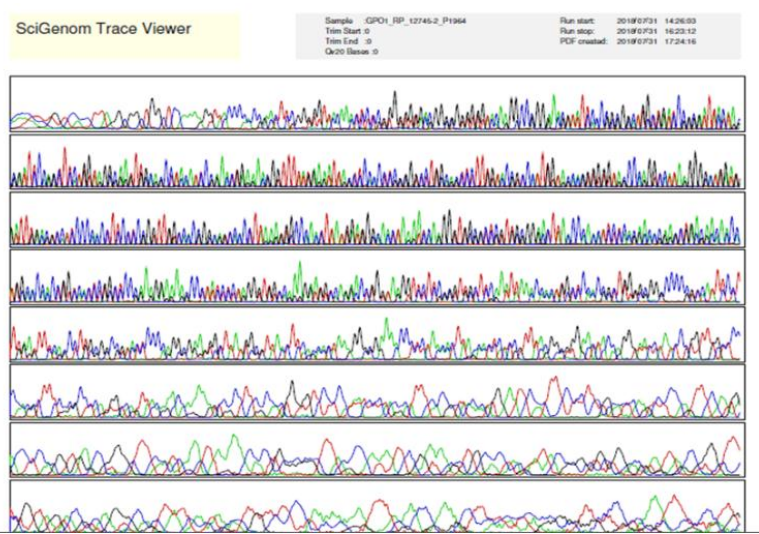

Fig.6 Sequencing (reverse primer)

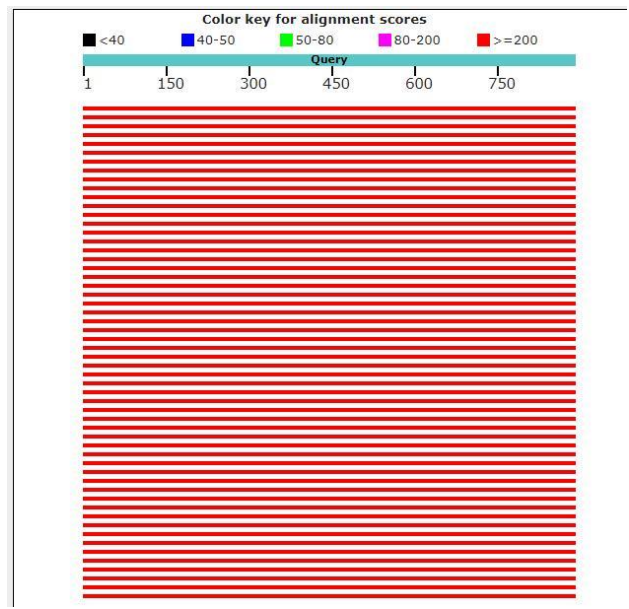

Fig. 7 BLAST Search 


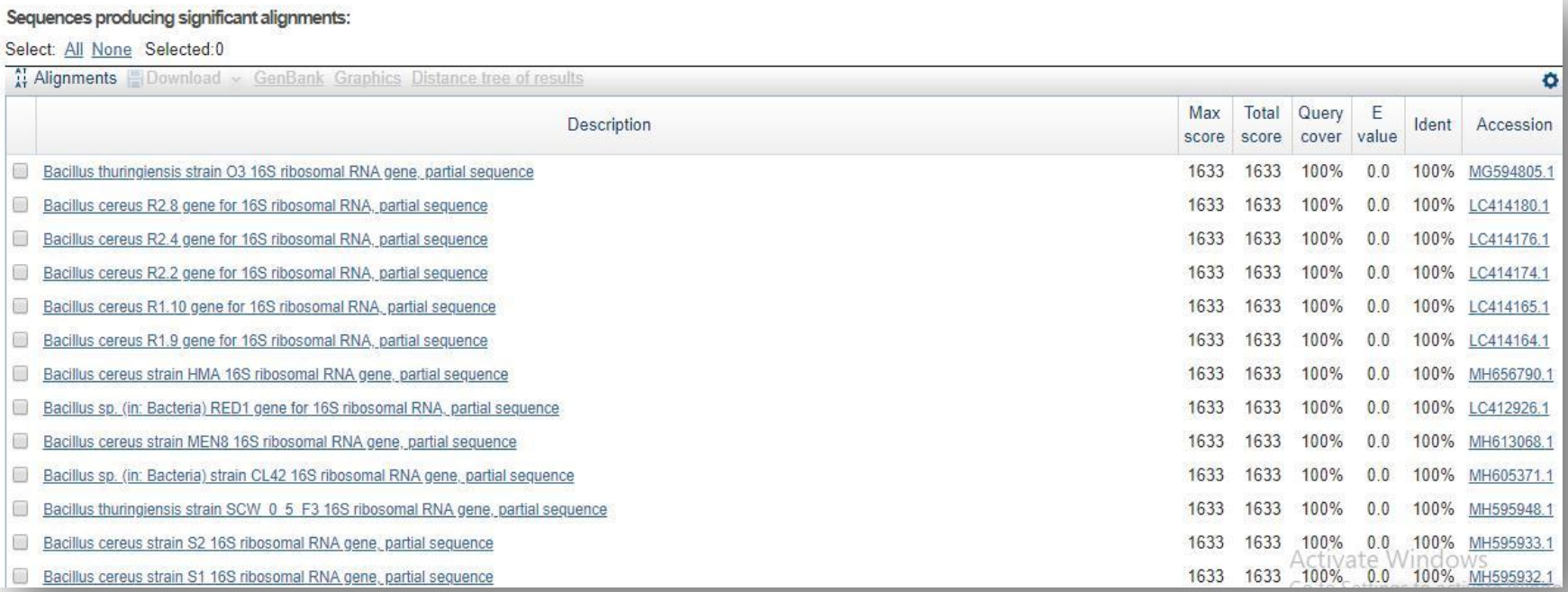

Fig. 8 Sequences Producing Significant Alignments

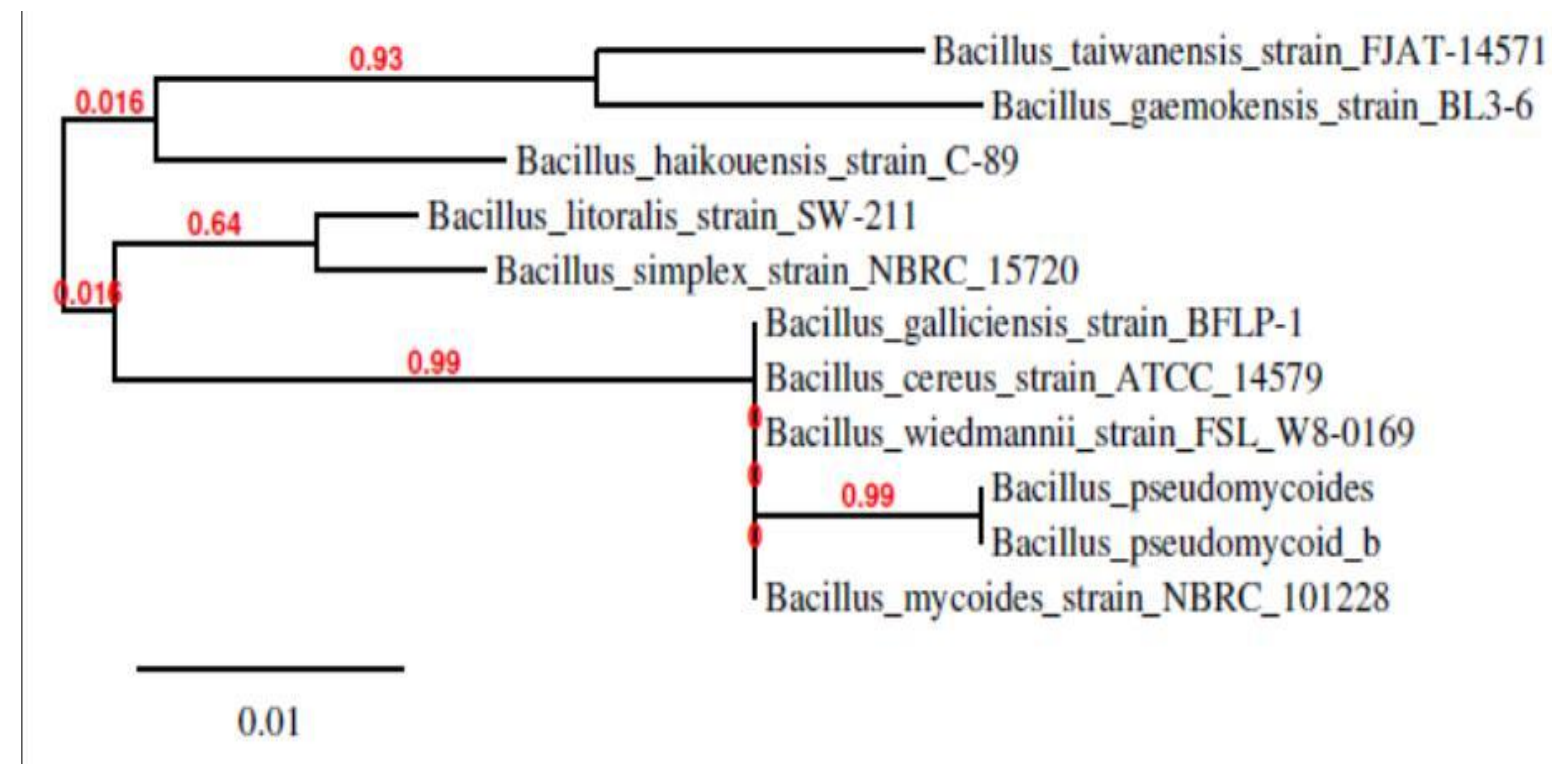

Fig 9 Phylogenetic Tree

\section{Optimization of Culture Conditions for gelatinase production}

For the maximum gelatinase production, the strain was optimized for various physico-chemical parameters. The $\mathrm{pH}$ of the medium was adjusted between 4 to 9 (fig.10), the optimum $\mathrm{pH}$ for maximum gelatinase production was found to be at $7(2.62 \mathrm{IU} / \mathrm{ml})$. The effect of temperature on the enzyme production was examined from $20^{\circ} \mathrm{C}$ to $60^{\circ} \mathrm{C}$ (fig.11) and showed maximum gelatinase production at $40^{\circ} \mathrm{C}(6.5 \mathrm{IU} / \mathrm{ml})$. The gelatinase enzyme production was maximum at $48 \mathrm{~h}(15.5 \mathrm{IU} / \mathrm{ml})$ of incubation (fig.12). The effect of different gelatin concentrations was examined (fig
13) and found to be maximum at $0.2 \%(36.07 \mathrm{IU} / \mathrm{ml})$. Optimization of various carbon sources (fig.14) showed lactose as the best source showing $3.93 \mathrm{IU} / \mathrm{ml}$ of gelatinase enzyme activity. 


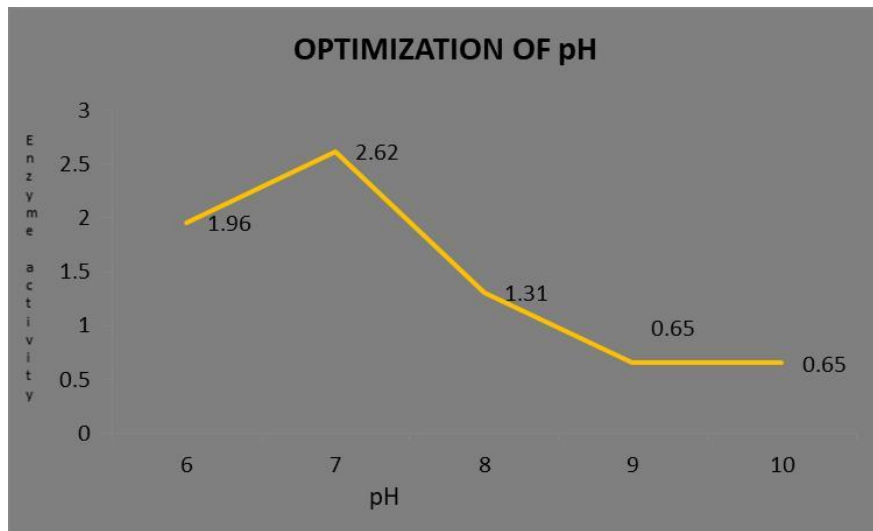

Fig.10 Optimization of pH

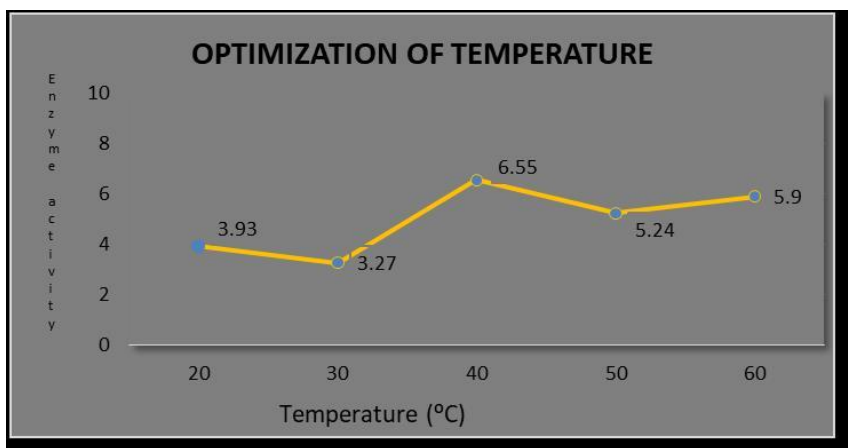

Fig 11: Optimization Of Temperature

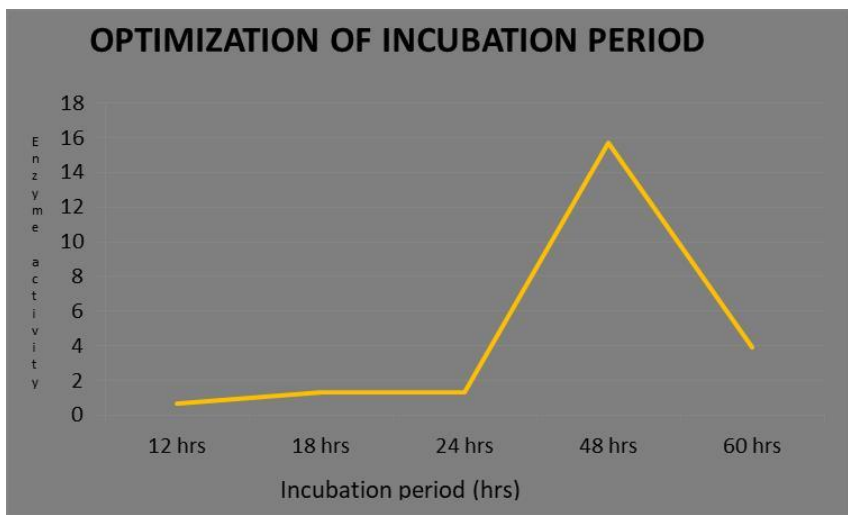

Fig 12: Optimization Of Incubation Period

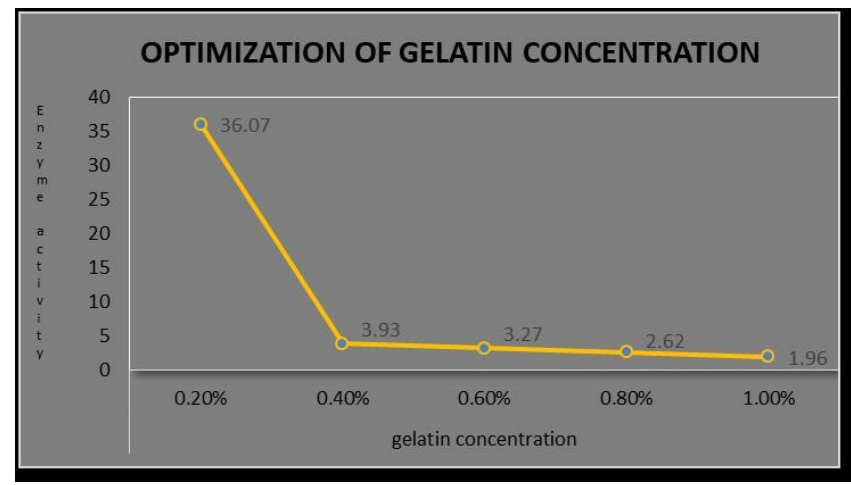

Figure 13: Optimization Of Gelatin Concentration

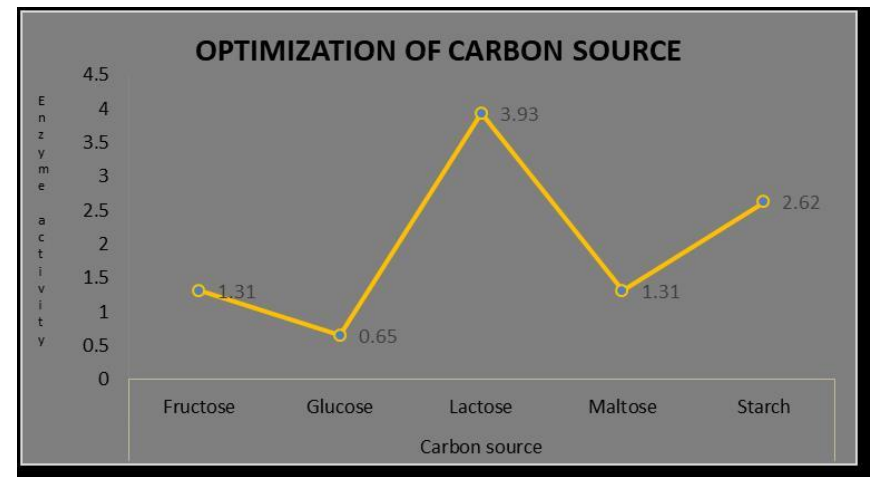

Fig 14: Optimization Of Carbon Source

\section{Partial purification of gelatinase:-}

These experiments were carried out to obtain the pure gelatinase from the crude enzyme extract which was collected from the fermentation experiments. The enzyme produced under all the optimum was then purified by ammonium sulphate precipitation (40\%) and dialysis. The final purification after dialysis yielded specific activity and fold purification of $45.85 \mathrm{IU} / \mathrm{ml}$ protein and 2 respectively(Table.3).The molecular weight of the partially purified gelatinase, as analyzed by SDS-PAGE, showed a single protein band of approximately having the molecular weight of $66 \mathrm{KDa}$ when compared with BSA as a standard (Fig 15)

Table 3: Purification of Enzyme

\begin{tabular}{|c|c|c|c|c|c|}
\hline Purification stage & $\begin{array}{c}\text { Volume } \\
(\mathrm{ml})\end{array}$ & Protein mg/ml & Enzyme Activity (IU/ml) & Enzyme/mg protein(L) & Purification factor \\
\hline crude & 50 & 16.8 & 22.9 & 1.36 & - \\
\hline $40 \%$ precipitation & 5 & 23.2 & 36.65 & 1.57 & 1.6 \\
\hline
\end{tabular}




\begin{tabular}{|l|l|l|l|l|l|}
\hline Dialysis & 5 & 28.0 & 45.85 & 1.63 & 2 \\
\hline
\end{tabular}

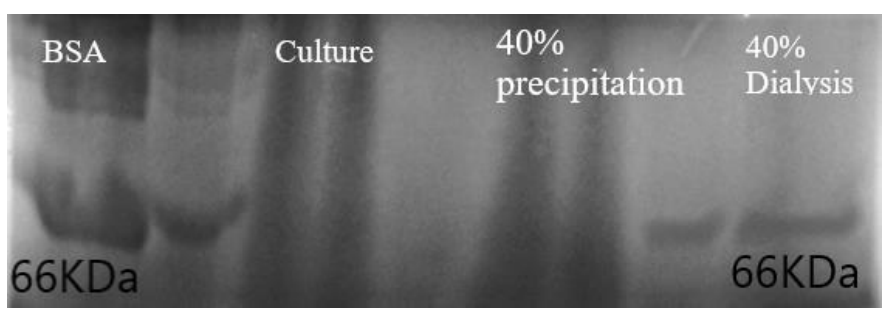

Fig 15 SDS PAGE

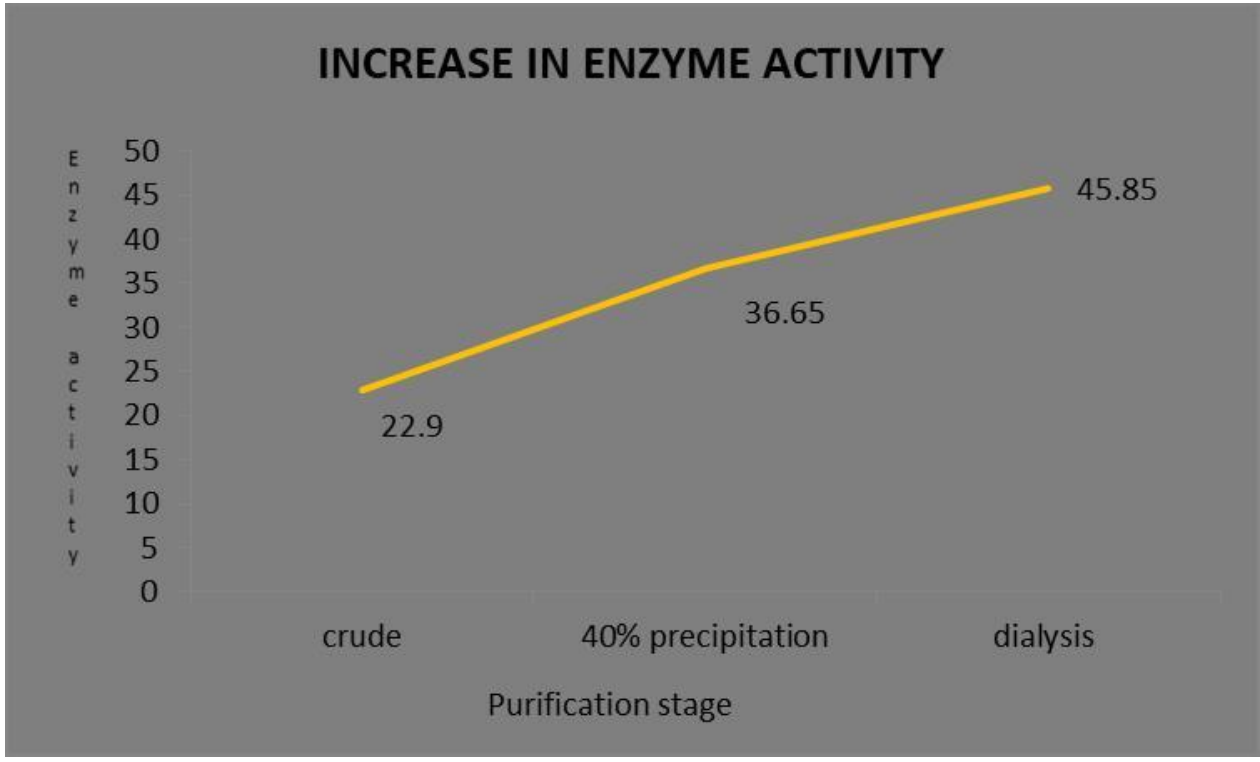

Fig 16 Increase in enzyme activity

\section{DISCUSSION}

Collagenases and gelatinases are important metalloproteases and their action are very specific, i.e., they acts only on collagen and gelatin substrates. Gelatinase is one type of diverse group protease, an extracellular metalloendopeptidase or metalloproteinase which is able to hydrolyze gelatin and other compounds such as pheromone, collagen, casein and fibrinogen. Gelatinase enzyme produced by microorganism hydrolyze gelatin into its subcompounds (polypeptides, peptides and amino acids) that can cross the cell membrane and be used by the organism. Forms of gelatinases are expressed in several bacteria including Pseudomonas aeruginosa, Staphylococcus aureus, Clostridium perfringens and Serratiamarcescens.

In present study, eight different samples were collected from different fish markets in and around Kolenchery, Ernakulam district. The gelatinase producing bacterias were initially analyzed for their ability degrade gelatin, for that the nine samples were pour plated on gelatin agar media and kept on incubation period of 48 hours, from that the isolate which show maximum gelatin degradation was selected (Figure 4.1). The isolate which showed zone of clearance after the incubation of $48^{\circ} \mathrm{C}$ in the gelatin agar plate was considered positive for gelatinase production and used for the further analysis. The clear zone formed in the gelatin plate indicates that the isolate have the ability to produce gelatinase enzyme. Samples labelled as GPO 1 and GPO 2 showed maximum zone and these strains were subjected to gelatin liquefaction assay for the conformation of gelatinase production. If gelatin was hydrolyzed, the medium will remain liquid after refrigeration. Both culture remained as liquid after refrigeration which indicates the production of geltinase enzyme (Figure 4.2).

The gelatinase enzyme producing strains (GPO 1) was subjected to universal primer based sequencing and analysis. 
Species-specific DNA sequences are used for the identification of bacterial species. The 16s-23s rRNA has proven useful for this purpose[31]. When compared to morphological and biochemical characterization methods, $16 \mathrm{~S}$ rDNA analysis was found to be the novel and accurate method for identifying unknown species. The DNA from the strain GPO 1 was isolated and the 16S rDNA was amplified using the primers (27F and 1492R) and sequenced. The partial amplification of $16 \mathrm{~S}$ rRNA was confirmed on the agarose gel electrophoresis. The BLAST analysis of the strain using its $16 \mathrm{~S}$ rDNA sequence data showed that strain (GPO 1) had highest homology (100 \%) withBacillus thuringiensis strain O3. Further the phylogenetic tree was constructed to identify the evolutionary relatives of the isolated strain.

The optimization of fermentation conditions, particularly physical and chemical parameters are of primary importance in the development of any fermentation process owing to their impact on the economy and practicability of the process. In the present study $40^{\circ} \mathrm{C}$ was found to be optimum temperature for growth of organism GPO 1 for gelatinase production. Data illustrated in Graph (Figure 4.14a) clearly indicated that the highest enzyme activity of GPO 1 was found to be $6.55 \mathrm{IU} / \mathrm{ml}$ protein at $40^{\circ} \mathrm{C}$. Similar result was observed using Bacillus haloduranswhich showed maximum activity at $37^{\circ} \mathrm{C}$ for protease enzyme production [32].

Like temperature, $\mathrm{pH}$ is also an important factor that influences the gelatinase yield. The results clearly showed that gelatinase production, expressed as enzyme activity, reached its maximum at $\mathrm{pH}$ of 7 and the enzyme activity was found to be showed $2.62 \mathrm{IU} / \mathrm{ml}$ protein. In the present study, the optimum $\mathrm{pH}$ was observed at 7.0 for GPO 1 growth for maximum enzyme production. However, according to previous study, the maximal protease yield was obtained from the culture Streptomyces pseudogrisiolus NRC - 15 at $\mathrm{pH} 9.0$ [33].

Further, experiment was conducted to test the suitability of different carbon sources such as glucose, starch, lactose, maltose, and fructose for gelatinase production and found that lactose was the best carbon source for the growth and showed a maximum activity of $3.93 \mathrm{IU} / \mathrm{ml}$ protein. A study described lactose did not influence significantly the production of gelatinase using Enterococcus faecalis[19]. In the present study, different gelatin concentrations such as $0.2 \%, 0.4 \%, 0.6 \%, 0.8 \%$ and $1 \%$ were examined in which peptone was found to be the most preferable for the growth and the enzyme activity was found to be $36.07 \mathrm{IU} / \mathrm{ml}$ protein at $0.2 \%$ of gelatin concentration.

Another important factor in which the gelatinase production depends on is the incubation period. When several incubation periods were analysed, an incubation of 48 hours (2 days) was found to be preferable for the organism for maximum enzyme production of $15.51 \mathrm{IU} / \mathrm{ml}$ protein.
Similar result was observed as $48 \mathrm{~h}$ was the ideal incubation period for protease production using Bacillus subtilis PE$11[34]$.

In enzyme fermentation process, the crude extracts contain different mixtures of proteins and undesirable products as organic acids and other metabolites. So that purification of the required favourable product must be take place by different purification methods [35].The gelatinase enzyme produced was purified using ammonium sulphate precipitation and dialysis. The specific activity observed by $40 \%$ ammonium sulphate precipitation was found to be $36.65 \mathrm{IU} / \mathrm{ml}$ protein and with regard to purification it showed 1.6 fold purification. The specific activity and fold purification after dialysis were found to be $45.85 \mathrm{IU} / \mathrm{ml}$ protein and 2 respectively.

\section{CONCLUSION AND FUTURE SCOPE}

In the present study we have isolated a bacteria designated as GPO 1 which produces gelatinase enzyme efficiently. By molecular identification using $16 \mathrm{~s} \mathrm{rDNA}$, the strain was found to have highest homology with Bacillus thuringiensis strain O3. The optimum conditions for submerged fermentation for the effective production of gelatinase enzyme with the isolated bacteria were recognized. Further, partial purification of enzyme with ammonium sulphate precipitation and dialysis yielded $45.85 \mathrm{IU} / \mathrm{ml}$ of enzyme activity. The purity of the enzyme preparation after partial purification was assessed by SDS- PAGE and molecular weight of the isolated enzyme was found to be approximately $66 \mathrm{kDa}$. Thus the study revealed that the isolated strain Bacillus spp has its potentiality for industrial scale production of gelatinase enzyme and the results will stand as a base line data for the production and application of gelatinase in future.

\section{REFERENCES}

[1].Buchholz, K.V. Kasche, U.T. Bornscheuer,"Introduction to Enzyme Technology",Biocatalystsand Enzyme Technology, pp: 1-26,2005.

[2]. N. Coello,L. Brito, M. Nonus, " Biosynthesis of L-lysine by Corynebacteriumglutamicum grown on fish silage",BioresourTechnol, Vol73 PP:221-225, 2000.

[3].J.A Vazquez, S.F Docasal, J. Miron, M.P. Gonzalez, M.A Murado, "Proteases production by two Vibrio species on residuals marine media", J IndMicrobiolBiotechnol 33, PP:661-668, 2006.

[4]. L.A. Underkofler, R.R. Barton, S.S Rennert,"Microbial process report: production of microbial enzymes and their applications", ApplMicrobiol, Vol 6, PP:212-221,1958.

[5]. G.M. Frost and D.A. Moss, " Production of enzymes by fermentation", In: H.J Rehm, G. Reed , J.F. Kennedy (eds) Biotechnology. vol 7a, VCH, Weinheim, pp 65-211, 1987.

[6]. R. Gupta, N. Gupta, P. Rathi, "Bacterial lipases: an overview of production, purification and biochemical proprieties", ApplMicrobiolBiotechnol, vol: 64, PP: 763-781, 2004.

[7]. N. Jacob, P. Prema, "Influence of mode of fermentation on production of polygalacturonase by a novel strain of Streptomyces lydicus, FoodTechnolBiotechnol, vol. 44, pp:263-267, 2006.

[8]. M. Palaniyappan, V. Vijayagopal, V. Renukal, R. Viswanathan, T. Viruthagiri, "Screening of natural substrates and optimization of operating variables on the production of pectinase by submerged fermentation using Aspergillusniger MTCC 281", Afr J Biotechnol, vol.8, PP:682-686,2009. 
[9]. A. Pandey, P. Selvakumar, C.R. Soccol, P. Nigam, "Solid state fermentation for the production of industrial enzymes", J Current Science, Vol.77, PP:149-162,1999.

[10]. M.M Pacheco, M. Mourao, E.B. Mantovani, I.N. Nishimoto, M.M Brentani, "Expression of gelatinases $\mathrm{A}$ and $\mathrm{B}$, stromelysin-3 and matrilysin genes in breast carcinomas: clinico-pathological correlations"Clin. Exp. Metastasis 16(7), PP: 577-585, 1998

[11]. W.G. Stetler-Stevenson, S. Aznavoorian, L.A. Liotta, "Tumor cell interactions with the extracellular matrix during invasion and metastasis" Ann. Rev. Cell. Biol. 9, PP: 541-573,1993.

12]. E.I. Deryugina and J.P. Quigley, “ Matrixmetalloproteinases and tumor metastasis", Cancer and Metastasis Reviews, Vol25(1), PP: 9-34, 2006.

[13]. O. Zitka, J. Kukacka, S. Krizkov, D. Huska, V. Adam, M. Masarik M, R. Prusa, R. Kizek, "Matrix metalloproteinases",Curr. Med. Chem, Vol. 17(31), PP: 3751- 3768, 2010.

[14].W.J. Lennarz, W.J Strittmatter WJ, “Cellular functions of metalloendoproteinases” Biochem. Biophy.Acta. 1071, PP: 149$158,1991$.

[15]. P. Makinen, K.K Makinen, "The Enterococcus faecalis extracellular metalloendopeptidase (E.C.3.4.24.30: coccolysin) inactivates human endothelin at bonds involving hydrophobic amino acid residues", J Biochem. Biophy. Res.Commun.200, PP: 981-985, 1994.

[16]. M. Tamaki, K. Tanzawa, S. Kurihara, T. Oikawa, S. Monma, K. Shimada,Y. Sugimura,"Synthesis and structure activity relationships of Gelatinase inhibitors derived from matlystatins", J Chemistry and Pharmaceutical. Bulletin, Vol. 43, PP: 1883-1893, 1995.

[17]. I.E. Collier, S.M. Wilhelm, A.Z.Eisen, B.L. Marmer, G.A. Grant, J.L. Seltzer, A. Kornberger, C.S. He, E.A. Bauer, G.I. Goldberg, "HRAS oncogene- transformed human bronchial epithelial cells (TBE-1) secrete a single metalloproteinase capable of degrading basemen membrane collagen", J Biol.Chem, Vol.263(14), PP: 6579-6587,1988.

[18]. R.M. Senior, G.L. Griffin , C.J. Filszar, S.D Shapiro, G.I. Goldberg, G Welgus, "Human 92 and 72 kilodalton type IV collagenases are elastases", J. Biol.Chem, Vol. 266(12), PP: 7870-7875, 1991.

[19]. P.D.P Boucas, E. Izumi, L.F. Maia, L. Sturion, S. Suzart, "Effects of environmental and nutritional factors on gelatinolytic activity by Enterococcus faecalis strains isolated from clinical sources", Afr. J. Microbiol Res;(10):969-976, 2008.

[20]. A.M Mazotto, S.M. LageCedrola, U. Lins, A.S Rosado, K.T Silva, J.Q. Chaves, L. Rabinovitch, R.B Zingali, A.B Vermelho, "KeratinolyticactivityofBacillus subtilisAMR using human hair", Letters in Applied Microbiology, Vol. 50(1), PP: 89-96, 2010.

[21]. A.M Mazollo, A.C.N. de Melo, A. Macrae, A.S. Rosado, R. Peixoto, S.M.L Cedrola, S. Couri, R.B. Zingali, A.L.V Villa, L. Rabinovitch, J.Q. Chaves,A.B. Vermelho AB, "Biodegradation of feather waste by extracellular keratinases and gelatinases from Bacillus sp" World J. Microbiol.and Biotech, Vol. 27(6), PP:1355-1365, 2011.

[22].ShanmugasundaramSenthilBalan, RajendiranNethaji, SudalayandiSankar and SingaramJayalakshmi, "Production of gelatinase enzyme from Bacillus spp isolated from the sediment sample of Porto Novo Coastal sites", A J Trop Biomed, S1811-S1816, 2012.

[23]. Maurice Ekpenyong, AtimAsitok, Abraham Odey, Sylvester Anta, "Production and activity kinetics of gelatinase by Serratia sp.SLO3, Nigerian Journal of Biopesticides, Vol. 1 (1), PP: 70-82, 2016.

[24].J.P.Harley, Laboratory exercises in microbiology, 6th ed. McGraw-Hill Companies, Inc., New York, USA, 2005.

[25]. M.J. Leboffe and B. E. Pierce, Microbiology laboratory theory and application, 3rd ed. Morton Publishing Company, Colorado, USA, 2010.

[26].L.H. Tran, H. Nagano H, "Isolation and characteristics of Bacillus subtilis CN2 and its collagenase production", J. of Food Science 67(3), PP: 1184-87, 2002.

[27]. H. Rosen,"A modified ninhydrin colorimetric analysis for amino acids", J Archives of Biochemistry and Biophysics, 67: 10, 1957.

[28]. H.M Hamza, S.M. Ali, H.G. Hassan, " Partial purification of Gelatinase enzyme from local isolate of Brevibacilluslaterosporus". Nat. J. Chem, Vol.23, PP:437-442, 2006.
[29].C.S Hoffman,F.Winston, “A ten-minute DNA preparation from yeast efficiently releases autonomous plasmids for transformation of Escherichia coli", GENE 57, PP: 267-272, 1987.

[30]. D.J. Lane, "Nucleic Acids Techniques in Bacterial Systematics", John Wiley \& Sons, Chichester, PP: 115-147, 1991.

[31].V. Gurtler, V.A. Stanisich, New approaches to typing and identification of bacteria using the $16 \mathrm{~S}-23 \mathrm{~S}$ rDNA spacer region" Microbiology 142, PP: 3-16, 1996.

[32].A.S.S Ibrahim, A.A. Al-Salamah, “ Optimisation of media and cultivation conditions for alkaline protease production by alkaliphilicBacillus halodurans" Res. J.Microbiol, PP: 251-259, 2009.

[33]. E.E.M Sayed, M.M Saad, H.M. Awad, M.H. Selim, H.M. Hassan, "Optimisation of media and cultivation conditions of extracellular proteases production from a newly isolated Streptomyces pseudogrisiolus NRC-15", E-Journal of Chemistry, vol.(2), pp:949961, 2012.

[34].S.A.U Qadar, E Shireen, S. Iqbal, A. Anwar,"Optimization of protease production from newly isolated strain of Bacillus p PCSIR EA-3”. Ind. J biotechnol, PP: 286-290, 2009.

[35]. D.J Mukesh Kumar, C.L. Poovai, Puneeth Kumar, Y. SushmaSaroja, A. Manimaran and P.T. Kalaichelvan,"Optimization of Bacillus cereus MRK1cellulase production and its Biostoning activity", Der Pharmacia Lettre, Vol. 4(3), PP:881-888, 2012

\section{AUTHOR PROFILE}

Dr.Jini Joseph is serving as Assistant Professor in Biochemistry since 2010 at St.Peter'sCollege,Kolenchery, Kerala under M.G University.

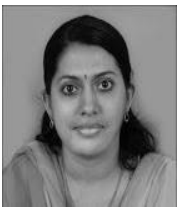

Harsha Sasidharan, secured MSc Biotechnology from St.Peter's college, Kolenchery in $2018.5^{\text {th }}$ rank holder of M.G. University, Kerala in Msc. Biotechnology 2018. Completed BSc. Biotechnology from St.Joseph's college, Irinjalakuda under Calicut University, Kerala in 2016.

Chithira O.S, secured MSc Biotechnology from St.Peter's college, Kolenchery under M.G. University, Kerala in 2018. Completed BSc. Zoology from St. Stephen's College, Uzhavoor under M.G. University, Kerala in 2016.
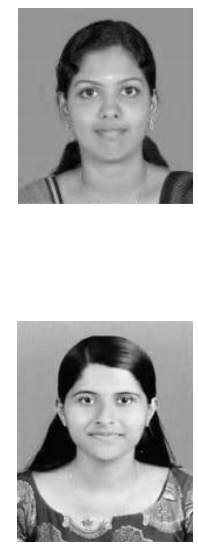